\title{
B16F0 melanoma exosomes deliver a unique and complex biological payload that includes Ptpn 11 to suppress T lymphocyte function
}

\author{
Yueting Wu, Wentao Deng, Emily McGinley, David J Klinke*
}

From 30th Annual Meeting and Associated Programs of the Society for Immunotherapy of Cancer (SITC 2015) National Harbor, MD, USA. 4-8 November 2015

\section{Background}

Host immunity is coordinated through a complex network of intercellular communication. Similar to the sculpting of tumor antigens during oncogenesis, a related hypothesis is that proteins secreted by malignant cells are shaped by somatic evolution. Malignant cells that then emerge secrete proteins that alter intercellular communication to promote tumor growth. As exosomes represent an emerging mode of cell-to-cell communication through the delivery of proteins and coding and non-coding RNAs, the objective of this study was to test this hypothesis by characterizing the impact of exosomes derived from three melanocyte cell lines on $\mathrm{T}$ cell function, with an emphasis on exosomal mRNA.

\section{Methods}

We analyzed exosomes from three melanoma models: B16F0, a non-immunogenic model of malignant melanoma; Cloudman S91, a model of immunogenic melanoma; and Melan-A, an immortalized melanocyte cell line.

\section{Results}

Using electron microscopy, exosomes derived from all three cell lines were morphologically similar and uniformly distributed in size. With a median size of $160 \mathrm{~nm}$ in diameter, exosomes were sized to remain within the tumor. The exosomes contained receptors derived from the parent cell as demonstrated by IL12RB2 expression on B16F0 exosomes and intact mRNAs. Furthermore, transcript profiling of B16F0 exosomes and cells suggested that exosomal mRNA is enriched for mRNAs that target immune-related pathways, including Ptpn11 that inhibited $\mathrm{T}$ cell proliferation and Dnmt3a that inhibited

West Virginia University, Morgantown, WV, USA
$\mathrm{T}$ cell production of IFN-gamma. Functionally, B16F0 exosomes dose-dependently suppressed cell proliferation and the expression of IL12RB2 in primary CD8+ T cells. In contrast, Cloudman S91 exosomes promoted $\mathrm{T}$ cell proliferation and Melan-A exosomes had a negligible effect on primary CD8+ T cells.

\section{Conclusion}

Collectively, the results are consistent with somatic editing of exosomal payloads and suggest that exosomes establish a density-dependent field effect by altering the activity of immune cells that enter the tumor microenvironment.

Published: 4 November 2015

doi:10.1186/2051-1426-3-S2-P270

Cite this article as: Wu et al:: B16F0 melanoma exosomes deliver a unique and complex biological payload that includes Ptpn11 to suppress $T$ lymphocyte function. Journal for ImmunoTherapy of Cancer 2015 3(Suppl 2):P270.

Submit your next manuscript to BioMed Central and take full advantage of:

- Convenient online submission

- Thorough peer review

- No space constraints or color figure charges

- Immediate publication on acceptance

- Inclusion in PubMed, CAS, Scopus and Google Scholar

- Research which is freely available for redistribution 